ARTICLE

\title{
Youth leadership and global citizenship: alternatives for peacebuilding in Brazilian public schools
}

\author{
Geraldo Caliman a \\ Ranilce Guimaraes-losif ${ }^{b}$ \\ Jose Ivaldo A. de Lucena ${ }^{c}$ \\ Vanildes Gonçalves dos Santos ${ }^{d}$
}

\section{Abstract}

Peace is a social construct that demands a process of individual and collective awareness and commitment for the construction of a fairer and more inclusive world. The University and the school, as formal educational spaces, have a great potential as peacebuilders. This article discusses these two arguments from fragments of an experience held in two public schools from Distrito Federal. It was conducted by the Unesco Chair on Youth, Education, and Society (Catholic University of Brasília - UCB) from 2015 to the present. The first part discusses the current context of young people from the theoretical lens of global citizenship and the centrality of youth leadership and empowerment in the process of peace building. The second part emphasizes the role of the university and the public school in the construction of networks that act proactively in the citizenship Education of young people, preparing them for facing situations of violence and intolerance. The final part of the article looks at the experiences of the last three years, examples of successful educational practices that have the potential to act in the prevention of school violence and in the construction of an inclusive and emancipatory global citizenship. The study shows that Unesco's principles of Education for peace and global citizenship are important alternatives for the promotion and building of peace.

Keywords: Youth Leadership. Global Citizenship. Cultures of Peace. Prevention of Violence.

\footnotetext{
a Catholic University of Brasilia/Unesco Chair on Youth, Education and Society, Brasília, DF, Brazil.

b University of Alberta, Alberta, Canada.

c Catholic University of Brasilia. Brasília, DF, Brazil.

d Catholic University of Brasilia. Brasília, DF, Brazil.
} 


\section{Introduction}

The text portrays a part of an experience of networking in favor of promoting a culture of peace among young people from public schools in the Federal District. The Unesco Chair in Youth, Education and Society of the Catholic University of Brasilia is one of the most important social insertion tools of the institution's Graduate Program, with one of its main purposes being the prevention of violence among young people.

Unesco has announced four pillars as principles of 21st century Education. These pillars are based on an existential dimension (learning to be); in an ethical dimension (learning to live together); a cognitive dimension (learning to know) and a technological dimension (learning to do) (DELORS, 1998). Based on Unesco's principles and goals of Education, the Chair has been working proactively to propose creative and innovative methodologies that promote spaces for youth leadership and interaction between students and university educators, as well as representatives of non-formal educational groups. The project has already been carried out in two public schools, with a group aged between 12 and 17 years, and the preliminary results point out the great potential of projects of this nature facing not only school violence but also educational, social and democratic gains for all involved in the process.

Despite acknowledging the contributions of informal and non-formal Education in this process, this article focuses on the interconnectivity between two formal educational environments: the university and the school. Based on Unesco's educational objectives (2015-2030), it proposes Education for global citizenship and sustainable development as strategies for achieving quality Education and for overcoming social problems. However, the text also highlights the potential for the articulation of the university made possible by Unesco's Chair 812 with partners working with youth in non-formal educational environments.

The methodology used in the research consisted of an analysis of the recent bibliography on the studied subject, contrasted with evidences of the experiences realized in the diverse meetings with students (group discussions) and teachers (focus groups). The basis for the formative meetings was, on the one hand, some principles of education based on the pillars of Unesco education and, on the other, dynamics in the area of social Education. 


\section{Cultures of violence}

Brazilian youth lives in a worrying situation when it comes to risks and vulnerabilities. The "Map of Violence 2016" shows how, on average, adolescents and young people are most involved in homicide and violence (WAISELFISZ, 2016). Some States are more worrisome than others. Maceió, the capital of the state of Alagoas, for example, tends to have high homicide rates, especially among young people. On the other hand, cities like Rio de Janeiro are in a true state of war in certain territories dominated by the traffic and the militias.

If we ask ourselves why there are so many homicides or so much violence, we would have to report on many factors. Among these factors, we can look at the history of Brazil, founded until the end of the nineteenth century on slavery, with a profound social inequality between social classes and the exclusion of citizenship rights of the majority of the population. Such inequality persists in a country that is among the most unequal in the world. A second explanation for the high levels of violence and homicide may also be the persistence of a culture that feeds on "values" linked to the law of the strongest, the difficulty to build spaces of tolerance and respect for diversity, and the persistence of opposition to human rights. "High inequality causes adolescents from social groups marked by social and racial exclusion to be the main victims of extreme violence and imprisonment" (SILVA; OLIVEIRA, 2016, p. 293).

Since the middle of the twentieth century, the members of the Chicago school reflected on the influence that culture exerts on the behavior of individuals. Shaw and McKay (1942) start from the observation of the existence of typical values in socially disorganized areas of the cities and, essentially, the problem of the transfer of these values. For other authors, such as Sutherland (1940), the solution is presented in terms of learning such values. Young generations learn the diverging cultural patterns of values prevalent in socially disorganized environments (slums). They are diffused along with other conforming and legitimate behavioral models. Initially, learning seems to be enabled by predominantly playful motivations, by curiosity, by the need to try something new or different from the everyday routine. In a second moment, the diverging cultural behaviors are supported by motivations of the utilitarian character and, finally, they become professional behaviors.

Miller (1958) in turn emphasizes subcultural interpretation and the importance of nonfamily groups in transmitting the values of violent subcultures. He focuses on juvenile delinquency and asserts that delinquency values are learned in a limited number of social groups, such as family, community, neighborhood, and peer 
group. Delinquency values pass from generation to generation. Therefore, they are transmitted by parents and community, learned and socialized by children. For the author, it is the low-income class that would more proficiently manage to preserve, transfer and socialize such values. Hence, the author seeks the causes of this learning in the socially disorganized slums that concentrate the lower class, whose values would conflict with those of the middle class, who would be dominant.

In turn, Hirschi's theory of social control (2005) finds in the affective bond with parents and institutions a strong motive for the integration of the person into conventional society. Others are involved in cultures of violence, not for the reasons described above, that is because they are not linked to people and values, but because they have been socialized within cultures that support violence: the group of peers, gangs, territories in situations of conflict and socially disorganized. As early as 1955, Cohen pointed out

in the language of contemporary sociology, she is saying that juvenile delinquency is a subculture. The concept of "culture" is familiar enough to the modern layman. It refers to knowledge, beliefs, values, codes, tastes, and prejudices that are traditional social groups and that are acquired by participation in such groups (COHEN, 1955, p. 12).

Studies on the cultures that generate violent and antisocial behaviors that developed in the middle of the 20th century have now their equivalent in more specific contexts. There is also a perspective based on the concepts of social exclusion of the involved individuals. Cultures of violence tend to be reproduced in the school environment where various types of violence are identified: from the school, in school, against the school. From the school, while the institution itself tends to be authoritarian and to configure undemocratic curricula and strategies. In school, because it is inserted in the surrounding territory, it tends to reproduce eventual cultures of violence that feed on the school (ABRAMOVAY; CASTRO; SILVA, 2016). Against the school, because it tends to be confused with the violent society and therefore deserving of the manifestations and expressions of displeasure and protest (GOMES et al., 2013).

In fact, some interpretations do not put their explanations on cultural learning, but rather on the issue of social unrest among young people, which tends to provoke expressions sometimes in forms of violence and sometimes in the form of drug use. The manifestations of violence are understood as symptoms of a discomfort that subsists in society (CALIMAN, 2008). Societies where children are violent 
would reap the consequences of the culture that underlies the social relations that permeate it. If there are problems, they would be found in the violent structures and cultures that reproduce themselves within the relationships that have developed in society. In this sense, symptoms such as violence are considered here expressions of a discomfort, a way of expressing, of saying that fundamental rights are being denied in the itinerary of those who need them to respond to the challenges that society itself imposes on childhood and youth.

There are problems in our society that can provoke such expressions of discomfort: cultural and structural conditions such as social inequality, nonfulfillment of fundamental rights, social exclusion. Poverty by itself does not seem to be a determining factor in violence-related behaviors. The association of various factors, such as feelings of dissatisfaction caused by social inequality, the frustration of fundamental rights, conditions of social exclusion can aggravate these conditions and facilitate consensus around marginalization cultures capable of reinforcing antisocial behaviors (CALIMAN, 2008).

In a publication entitled "Cultures of Violence Cultures of Peace", Unesco's Chair 812 deepens the relationship between adolescence and violence in the perspective of education for a culture of peace. Gomes et al. identify several interpretive perspectives of adolescence in which the relations between culture and behavior are prefigured, as well as create methodologies for overcoming cultures of violence. One of them is called the perspective of subjectivity,

[...] a humanistic educational perspective, according to which the adolescent, in the conquest of his identity, lives the crucial experiences of the subject, as an individual in the sociocultural context. [...] the adolescent is inserted in the historical-social and cultural context as a subject. [...] The school should create practices that provide conditions for young people to learn and understand their personal participation in the struggle for a future with social justice and political integrity (GOMES; NASCIMENTO; KOEHLER, 2012, p. 36).

Since classical sociology has shown signs of exhaustion, new alternatives of understanding are sought, such as the sociology of experience (DUBET, 1994), as well as of Social Pedagogy (CALIMAN, 2019). It has demonstrated the potential to act as a methodology laboratory capable of designing public policies at nonformal education level, as well as in the field of school management, curriculum, and school practices, aimed at developing cultures of peace and citizenship in schools with the aim of preventing violence (CHRISPINO; DUSI, 2008). 
To understand this reality more deeply, it is necessary to understand not only the social reality which is offered to us by the Social Sciences, but also the methodologies offered by the area of social education that allow us to create appropriate pedagogical practices and processes for each situation. Culture, as an expression of human subjectivity and interactivity, manifests itself as an indispensable resource for education, in particular, Social Education.

\section{Education for citizenship and the promotion of cultures of peace}

One of the most viable alternatives for responding to situations of violence may be listening attentively to what young people have to say. These are methodologies and educational processes enshrined in the scope of Social Education, capable of generating empathy between educators and young people. The prevention and confrontation of violence necessarily involve actions aimed at promoting cultures of peace in areas where it is possible to reach as many children and young people as possible (ALMEIDA; OLIVEIRA; BRUM, 2019; BOSCHI, 2018; DISKIN; NOLETO, 2010; PELIZZOLI, 2015; VASCONCELOS; LIRA; SOARES, 2019). Given this argument, in addition to working with the Teaching of scientific content, the school that seeks to promote peace cannot relinquish its role in the democratic discussion about issues that contribute to the citizenship of young people, whose actions have local and global impacts.

Incheon's (UNESCO, 2015) statement stresses the importance of developing education systems that are more inclusive and resilient in the face of the needs of children, youth, and adults, ensuring that education takes place in warm, safe, and free from violence environments. The document highlights the role education can play in education for global citizenship--a strategic path for promoting sustainable development-- quality education and a more inclusive society. In this context, the Declaration emphasizes the importance of the global citizen, who makes conscious decisions and responds to local and global challenges, taking into account human rights and the defense of cultures of peace. Understood as a public good, Unesco (2015) reaffirms that education is a fundamental human right and of high relevance for the promotion of peace, tolerance, human achievement and sustainable development.

Noleto (2004) emphasizes that education for a culture of peace includes understanding, solidarity, and respect among people of different countries, races, gender, religions, and generations. The author draws attention to Unesco's contributions to the definition of public policies that recognize young people and 
their multiple needs, becoming a global pioneer in defense of a culture of peace and in the adoption of transformative educational practices to combat violence.

Guimarães-Iosif and Shultz (2015) emphasize an education that defies violence, transforms conflicts, demands change in one's own pedagogical practices, getting closer to the realities experienced by children, youth, and educators. In this process, it is crucial to create more democratic spaces in educational settings that engage young people and educators in the public debate on human rights, democracy, peace and social exclusion. However, it is essential for students to feel part of the process and to be aware of the contributions their actions can bring to transforming violent and unequal social contexts.

Performance and meritocracy impregnated in education policies seek good results in exams as the primary focus of the school, reducing the space for young people to express their opinion and also learn to listen and respect the opinion of others. The restriction of spaces for dialogue and democratic coexistence between young people and educators contributes to situations of conflicts that, without proper facilitation, end up turning into cases of violence.

A young man arrives at the school with his history and cultural baggage. The way the school interacts with his previous experiences and knowledge is determinant for the forms of interaction and learning (FREIRE, 2005). For Guimarães and Shulz (2015), the biggest challenge is to make the school seen by students, teachers, and parents as a safe space for learning, socialization, dialoguing and fostering partnerships, not as a prison surrounded by walls and rules that cannot be questioned or discussed by those who are not directly involved in school management. In this scenario, the strengthening of democratic management and school partnerships with other educational environments, whether formal or non-formal, can provide a unique contribution to carrying out projects that increase young people learning possibilities, directly impacting the prevention of violence in the school and society in general.

In contexts of promoting cultures of peace, citizenship needs to be thought of as a collective construction that is not limited to the legal dimension, delimited by the fact of being born or not in a particular Nation-State. Citizenship encompasses social, cultural, historical, ethical, democratic and emancipatory elements fundamental to strengthening social justice and human rights in local, national and global contexts.

Sometimes I think that we speak of citizenship as if it were a concept, very abstract, with a particular magical force, as if, when the word 
citizenship was pronounced, automatically, everyone would win it. Or as if it were a gift that politicians and educators gave to the people. It's not that. It must be made clear that citizenship is a production, a political creation (FREIRE, 2005, p. 127).

The citizenship education model capable of promoting the democratic and emancipatory changes necessary to confront the current situation of exclusion and violence recognizes the dialogue between different forms of knowledge. Therefore, it is necessary to listen and understand in depth the alternatives for the development of citizenship presented by young people from different educational contexts, such as basic education, higher education, continuing education or popular education, held in the space of non-formal education.

\section{University and its social function to public schools}

As we report at the beginning of this article, we are presented with a complex reality, as is the case of Brazil, historically marked by situations of violence where human rights are often disregarded. Many lives are taken, especially among young people who are victims and perpetrators of violence at the same time, as we can see from the research data developed by Flacso (ABRAMOVAY; CASTRO; SILVA, 2016): four out of ten students report having suffered violence inside the school and in $65 \%$ of cases committed by colleagues themselves. Among the types of violence are physical aggression, threats, cyberbullying, robbery, theft and sexual violence. How to intervene in such reality, but through the creation of a new reality, the development of projects that spread cultures of peace, with the collaboration of forces from different actors, the exchange of knowledge and the sensitivity of different looks. It is in this logic that we recognize the importance of the partnership between School and University in projects that are dedicated to an education for citizenship and sustainable development.

If we assume that individuals learn to live and practice violence, that is, that it is based on cultural matrices, that violence is learned, we can presume that cultures of peace are also learned and, for that, socializing spaces play a key role. As Gadotti (1997) asserts, school is a major place of education and not of any education, but of an education contextualized and therefore capable of giving answers to the challenges that reality presents to it. In the Brazilian case, it is understood that the reality challenges us to the activation of full citizenship, understood by individuals conscious of their rights and duties and the exercise of democracy. For this, it is necessary to have strategies for the activation of educational processes that are capable of articulating institutional resources in networks proactively acting in the education of young people, and methodologies 
tailored to the development of critical thinking that empower them so that they themselves are able to construct responses to the confrontation of the factors that generate situations of violence.

Two important elements of this network can be identified at the realm of research and knowledge on the one hand (the University), and the realm of educational dynamics for young people, on the other (the School). The university plays a particular role, not only because it recognizes the need to involve research and knowledge, but also because of its potential to provide support for young students to play their part in building a culture of peace, as opposed to cultures of violence.

The process of building peace cultures is not absent from conflicts and tensions since social spaces are composed of people intertwined in power relations, whether in the family environment, in the territory or at school. For that, the methodology involving adolescents in the awareness of the risks they face tends to promote the empowerment or the qualification to deal with conflicts management with different attitudes and behaviors, preventing and reducing violence and intolerances.

The Salamanca Statement (CORDE, 2004) shows that the university is an important partner in the construction of democratic school processes. Considering that through its Research, Teaching and Extension triad, the university has as one of its tasks the social commitment to the community, contributing to the improvement of human life in society (SEVERINO, 2007).

From the dialogical practices between the public school and the university, the knowledge that is produced benefits both as they are opportunities to reflect on their practices, to implement pedagogical alternatives that arise from reflecting upon developed activities. For the universities, the contact with the schools and their actors collaborates to the construction of the professional identity of its students. This is what we have seen in the project presented here, where Unesco's 812 Chair on Youth, Education and Society, understands the meaning of the university's social commitment, as well as its own commitments as part of Unesco's network. The project involves the collaboration of university students from different areas of knowledge, thus being a rich space of direct and concrete contact with realities in which they have the opportunity to confront theories in classrooms, as we can identify in the following statements of two graduating students collaborating in the project:

Having participated in the project was enriching for my academic training and for my personal growth. The project opened the doors 
to shared thinking, providing new conceptions. As a future teacher, it was extremely important to have had this contact. I learned a lot with teenagers. Their speeches allowed me to have a more critical, reflective, human and understanding look (Pedagogy undergraduate student, 24 years old).

This contact, through projects elaborated according to methodologies that are attentive to local reality and that favor participatory processes of knowledge construction and exchange of experiences, draws inspiration from Freire's pedagogy where the exercise of learning and Teaching is for everyone, making all learners (FREIRE, 1998) of new ways of dealing with oneself, with others and with the planet, acting locally, but thinking globally. In this sense, a law student, who acted as the facilitator in one of the workshops held in one of the schools, expressed:

It was interesting to see how the Interschool Language Center of Taguatinga (Cilt) already has this social, ecological and sustainable concern through the waste sorting and other actions, but to see that one more seed was planted in those young people, not only for the improvement of the school facility, but seeing them talking about actions that were discussed there that can be taken to their daily and family routines. I was delighted with the group I helped in the workshop (Law student, 29 years old).

The participation of university students in the civic education of young people of the Public School (Cilt) makes education, research, and social commitment happen in an inseparable way for the university to fulfill its training goals, becoming a locus of learning ambiance. Thus, knowledge is acquired no longer through products, but through its processes (SEVERINO, 2007; SIVERES, 2013).

\section{School, youth leadership and global citizenship}

We understand that a school should be contextualized in the surrounding environment, in its territory. In this sense, in addition to its functions linked to Teaching and learning processes, the school is also a space for social integration and personal development of students. Hence the need to create strategies that promote the interaction between the school environment and the external environments experienced by the students, so that they can think and rethink their attitudes, developing critical sense, ethics, citizenship, justice and the promotion of a culture of peace. 
The interaction between school and reality of the territory responds to the need to rescue, create and foster in students values such as: collaboration, coexistence, attention, honesty, respect, responsibility, preservation of the environment and public patrimony, critical and moral sense, thus contributing, for a better quality of life in the school community.

The first experiment was developed at the High School Center 03 (CEM03) in Taguatinga Sul-DF. Two 40-hour courses were held, one in the second half of 2015 and the other in the first half of 2016, with 30 high school student leaders in each class. University students and volunteers participated in the project, led by the Cathedra 812 of Unesco; among them the Taguatinga High School 03 (CEM 03), the Graduate Program in Education of the Catholic University of Brasilia (UCB), the Middle School Intermediate Coordination of the Regional Board of Education of Taguatinga and university students of UCB majoring in Pedagogy, Law and Psychology.

The general objective of the training was to "foster the creation of alternative spaces in the school for the promotion of the active citizenship of the students and development of leadership that contributes to the composition of a culture of peace". To achieve this goal, we seek: a) to mobilize students for the creation of the student government; b) contribute to the promotion of student leadership aimed at promoting a culture of peace at school and in society; c) integrate the concept of citizenship and rights and duties into the school space.

This initiative considered the Pedagogical Political Project of the Public School, mainly linked to the actions linked to the Educational Guidance Service and the Diversified Part of the Curriculum. In addition, the project met the goals of the Ministry of Education's Innovative Higher Education (Emei), which reinforced the importance of the creation of the student government in the school and the formation of alternative spaces for education for citizenship and for the promotion of a culture of peace in schools.

The project called "Youth and Citizenship in Action" provided the training from the following themes: Identity (being young: how do I see myself? How do I see the world?); Youth Leadership, Conflict Mediation (in school, in the community and in the relationship between parents and children); and the use of technologies to overcome cyberbullying.

The theoretical-experiential methodology enabled the development of students' communication skills, as well as the capacity to deal with daily conflicts through 
non-violent communication. The project has the pedagogical strategy of valuing the experiences brought by the students and the collective construction of knowledge through debates and reflections, mediation simulations of pedagogical cases and real situations experienced or witnessed in the school or community context, besides reading and study of texts.

The following were used as pedagogical resources: articles for deepening concepts, videos, music and thematic games that provided the mastery of contents and the strengthening of friendship bonds, mutual respect and social, community and school engagement from a personal life's perspective. Participants evaluated the meetings positively. One of them, who participated in the project and today attends a university, expresses about the impacts of the project in his life:

The training provided at the High School Center 03 by Unesco Chair 812 was comprehensive, as we had experiences from various areas (gender, leadership, conflict mediation, cyberbullying, youth leadership), which greatly helped both my academic and personal development. What influenced me the most and what I found most important was the non-violent conflict resolution, as I learned how to resolve my own conflicts and helped colleagues to resolve theirs in a non-violent way. When applying this learning to my real life, I see it really works. The experience contributes to violence prevention and a culture of peace because it helps us to understand each other better. It also contributes to more authentic and less violent relations through the practice of communication and empathic dialogue between people. In the workshop on life project, I learned to better open myself and channel my energies to what is most important. I was approved at the University of Brasilia for the English Language course and believe that this achievement was the result of the training I had in the public school and especially the Unesco-UCB Chair extension project (CEM 03 Student who participated in the Extension Project).

The evaluation used a procedural approach, aiming to observe the participation of the students through observation of the accomplishment of the activities and in a continuous way, considering the process and not only the product. In this sense, the aim was that the students become transmitters and multipliers of what was learned in the project to the family, in the neighborhood and to the other classmates.

A new experience began in the second half of 2016, when the extension project began to take place in the form of large meetings of public school youth leadership 
development, in the Taguatinga Interschool Language Center (Cilt), one of the schools of the Federal District associated with Unesco.

In today's world, mastery of a second language greatly extends the possibilities for educational and professional success of young students, projecting them to assume leadership positions in local and global spaces. Based on this premise, Unesco Chair 812 and the Cilt took the initiative to carry out the extension project, which aimed to establish and/or strengthen a network of partnerships with schools, universities and national and international institutions. These networks create more opportunities for students to improve their language skills through activities with students from other cities, states, or countries, and also enhance their leadership skills and their sense of belonging to a global citizenship.

In a context marked by serious social and political problems, Brazil urges citizens to be participative and aware of individual and collective rights. In this perspective, education for citizenship is ensured as one of the ultimate goals of national basic education, as determined by the Brazilian Federal Constitution (BRASIL, 1990), the Law of Guidelines and Bases n. 9.394/96 (BRASIL, 1996) and the National Education Plan (BRASIL, 2014).

In this scenario, both the school and the family can collaborate with the citizen education of students. The Cilt, with about 5,000 students, mostly from the public school system of the Federal District, has as the general objective of its Political Pedagogical Project "to properly teach the modern foreign language with the expectation that students have basic, intermediate and advanced linguistic mastery" and contribute to the formation of "citizens able to participate in the social and economic development of the place where they live." Among the specific objectives, it is possible to highlight the care with an education focused on learning and intercultural respect; training for participatory, critical, reflexive and responsible citizenship; and cooperation and communication with peoples of different cultures, ethnicities, and languages.

The objective of this edition of the Unesco-UCB Chair extension project was to promote activities that contribute to the development of young citizens who adopt a position of local and global leadership in promoting a culture of peace and human rights.

In the second half of 2016, the first meeting held at the Cilt was held, with the theme "Youth Leadership and Global Citizenship". It was attended by 121 students, distributed in 20 workshops that discussed among other concepts: Citizenship, Global Citizenship, Youth Agency, Social Commitment, Engagement, Youth 
Leadership and Dream. The workshops were coordinated by students of several courses of UCB. It culminated with the principles for a collective letter on "Being a citizen in local and global perspectives." The letter that was presented in Canada from March 3 to 10, 2017, at the Youth Forum held by Unesco, where the Cilt gave the opportunity for a teacher and a student to represent public schools in Brazil. That provided a significant experience for the life of the student, which is expressed as follows:

Representing the Cilt, my city, my country and my colleagues was one of the most important experiences of my life. With young people from other countries, I was able to participate in the Unesco Conference Education 2030 Agenda and live with totally different cultures, as well as contribute to the International Youth White Paper on Global Citizenship and show that we, the youth, have a voice which deserves to be heard and has the power to change the world. From that experience, my life projects have expanded, I became a better individual who cares about the world and who knows that the time to transform the future is now (Young student of Cilt, 15 years old).

In the first half of 2017, the second meeting of the Cilt aimed at promoting a reflection with students about "Youth, sustainability, and citizenship", with the goal of developing commitments: personal, school and community, for caring for the well-being and harmony with the planet, thinking globally and acting locally. These commitments were made by the students representing the entire educational community of the school. Among the objectives of this meeting we highlight: a) discussing sustainability and its dimensions; $b$ ) raising awareness for the construction of sustainable relationships in the daily life, school, and community; c) making commitments to be experienced in personal, school and social daily life. In this edition we had the participation of 140 students from several public schools of the DF, who are also students of the Cilt, for whom the experience was a learning opportunity:

The meetings bring an additional knowledge that we do not learn at school in our daily life (Student 2 - Focus Group held in the Cilt).

The methodology and the themes of the meetings change the perspectives of young people, because they help us to think about the things that happen in the world (Student 5 - Focus Group held at Cilt).

Our schools have not worked for a culture of peace as they should, so they create space for violence (Student 3 - Focus Group on Cilt). 
The meetings have challenged us to make a difference in society, to seek other forms of relationship with ourselves and with others (Student 5 - Focal Group in the Cilt).

In the second half of 2017, the third meeting of the project in the Cilt, which had as its theme "Youth and Social Networks: Citizenship and Sustainability", aimed at discussing with students social networks as space for youth to promote citizenship and sustainability. In this edition, we had the participation of 138 young people distributed in several workshops facilitated mostly by young volunteer students of UCB and also teachers of the Cilt. The following young people's speeches demonstrate how they evaluated the meaning of the activity:

It takes us out of the comfort zone and makes us think about daily questions that we usually don't pay attention to and don't know the context behind them, as the example of Social Media (Student 3 Focus Group held at Cilt).

The forum helped us to understand how the violence can be present in social media and how we have to take a stand in a critical way for not being manipulated by it (Student 4 - Focus Group held at Cilt).

In this project, we used a methodology that consisted of three stages: The first being the training of the facilitators. Two meetings were held, one at the university and another at the Cilt, where the workshop proposals were presented, experienced and expanded with suggestions from the participants, a group formed by UCB students and Cilt teachers. The second stage was comprised by the workshops, which took place on Saturdays, from 8 am to 11:30 p.m. And the third moment was the evaluation of the activity, where the workshop proposal was taken up to check what had or had not worked, so that adjustments could be made to the next edition. The dynamics of the activities on Saturday were marked by three major parts: Welcoming cultural presentation to make participants sensitive to the theme of the workshops; the workshops that had active methodologies that allowed the interaction between young people and the theme in focus. And the closure, where the results of the workshop, which were usually commitments or elaborate principles were presented.

Participant students expressed the following about the used methodology:

The different topics at each meeting have provided new learning, including to be taken to class. I have managed to apply them in 
the classroom, beginning to engage students through the content worked on the meetings. I find that the students have shown interest (Teacher 4 - Focus Group held at Cilt).

The partnership with the Unesco-UCB Chair has been productive and has been broadening the teachers', school management's and students' horizons. What could be improved is the school learning how to expand this experience for more students (Teacher 1 - Focal Group held at Cilt).

This partnership has broadened our horizons, as reflections are essential, especially for the public schools that do not have resources, not to mention that it is a voluntary project. The school needs volunteers, but not any kind of volunteer (Teacher 2 - Focal Group held at Cilt).

Regarding the promotion of a culture of peace and violence prevention in school, which is one of the focuses of the project, teachers have realized that:

The relationships in our school are good because the students stay less time in the classroom and the classes are smaller, the teachers have a good control of the class, when a conflict arises they act soon to help solve it. In the trainings and workshops, we began to reflect and work better with our students, reproducing this. Things may be in the minds of our students and we never stop to reflect on it (Teacher 2 - Focus Group held at Cilt).

Regardless of whether or not we have a problem in school, students are multipliers, because they take what they learn to their environments, whether to the other school or at home, with neighbors or friends (Teacher 1 - Focus Group held at Cilt).

The perceived results are in terms of a better coexistence among the students, as well as in their collaboration for the construction of a culture of peace in schools and in their communities. Simple everyday attitudes can contribute more effectively to dealing with violence, both in schools and in communities, through a more human communication style based on non-violence, sustainability, and harmony between people. When called upon to reflect critically on the surrounding world, youths have great potential for spreading another culture to another possible world, where justice, peace, and solidarity are at the center of relations between peoples and nations. 


\section{Final considerations}

The research and implementation of new working methodologies with young people based on cooperation, dialogue, listening and social engagement of young people in their different realities provided a learning experience for both public schools and university.

It is suggested for the next projects the involvement of young people who participated in the previous stages to act as protagonists, composing the methodology and workshop teams. This perspective contributes to youth leadership development that can support the continuity and sustainability of the project activities with an ever more youthful language for young people.

The methodology being dynamic, engaging and interactive was very well accepted by the young participants, given that the meetings were spaces for listening and expressing students' concerns, dreams and suggestions. In fact, the dynamics used for the meetings were based on methodological principles inspired by the social dimension of education (CALIMAN; VASCONCELOS, 2019) sought to stimulate: (a) the primacy of human relations over Teaching-learning processes; (b) Informal dynamics: social pedagogy, through its application in social education, uses predominantly informal dynamics to facilitate relationships among young people; (c) the affective dimension, which acts to improve the quality of coexistence, the exercise of citizenship, in learning conflict resolution methods; (d) the combination of learning (knowing) and social responsibility (living together).

We proposed as an objective the diffusion of a culture of peace among the students of two schools. The experiences allow us to perceive that there are many elements that emphasize such principles, such as:

1. In the field of learning to know:

a) Discussion and study of themes that contribute to the students to perceive themselves as protagonists and potential transformers of their reality;

b) Collective appropriation through creative approach to content such as culture of peace, citizenship, sustainability, human rights and new technologies.

2. Learning to do:

a) Activities with which students contribute ideas for the elaboration of the pedagogical political project, plant trees, elaborate thematic murals 
and even paint the school with pictures that represent their identity and artistic and cultural expression.

3. Learning to live together: The fundamental part of the work was

a) The collective construction of knowledge through interaction and exchange of experiences in the circles and conversation and in the experiential workshops;

b) The socialization of the works developed in the meetings with other students through the elaboration of thematic murals.

4. Learning to be:

a) The project as a space for listening and empathic dialogue among students so that they can reflect on their identity and insertion in the world;

b) Themes were suggested by the school in line with the demands that students presented about issues that challenge them in contemporary times.

Critical reflection on the reality motivated young people to discuss the social reality that they are part of, as well as alternatives for overcoming violence and building a culture of peace and sustainable relationships, from everyday life, whether at school or in the community. 


\section{Liderança juvenil e cidadania global: alternativas para a construção de paz em uma escola pública}

\section{Resumo}

A paz é fruto de uma construção social que demanda um processo individual e coletivo de informação e compromisso na construção de um mundo mais justo e inclusivo. A Universidade e a escola, enquanto espaços de Educação formal tem um grande potencial como promotores e construtores de paz. O artigo discute esses dois argumentos a partir de uma experiência desenvolvida em duas escolas públicas do Distrito Federal pela Cátedra Unesco de Juventude, Educação e Sociedade da Universidade Católica de Brasília (UCB), a partir de 2015 até o presente. A primeira parte discute-se o presente contexto da juventude a partir de um foco teórico na cidadania global e na centralidade da liderança juvenil para a apropriação de processos de construção de paz. A segunda parte enfatiza o papel da universidade e da escola pública na construção de redes que atuam proativamente na Educação dos jovens para a cidadania, preparando-os para o eventual confronto com situações de violência e intolerância. A última parte do artigo volta-se para as experiências de sucesso dos últimos anos, capazes de ativar a prevenção da violência escolar e a construção de uma cidadania global. O estudo mostra que os princípios de Educação para a paz e formação da cidadania global inspirados na Unesco são importantes alternativas para a promoção e construção de culturas de paz.

Palavras-chave: Liderança Juvenil. Cidadania Global. Culturas de Paz. Prevenção da Violência.

\section{Liderazgo juvenil y ciudadanía global: alternativas para la construcción de la paz en escuelas públicas brasileñas}

\section{Resumen}

La paz es fruto de una construcción social que demanda un proceso individual y colectivo de información y compromiso en la construcción de un mundo más justo e inclusivo. La Universidad y la escuela por ser espacios de Educación formal tienen un gran potencial como promotores y constructores de paz. El artículo discute estos dos argumentos a partir de una experiencia desarrollada en dos escuelas públicas del Distrito Federal por la Cátedra Unesco de Juventud, Educación y Sociedad de la Universidad Católica de Brasilia (UCB), a partir de 2015 hasta el presente. La primera parte discute el presente contexto de la juventud a partir de un enfoque teórico enfocado en la ciudadanía global y en la centralidad del liderazgo juvenil para la apropiación de procesos de construcción de paz. La segunda parte enfatiza el papel de la universidad y de la escuela pública en la construcción de redes que actúan proactivamente en la Educación de los jóvenes hacia la ciudadanía, preparándolos para el eventual enfrentamiento de situaciones de violencia e intolerancia. La última parte del artículo se vuelve a las experiencias de éxito de los últimos años, capaces de activar la prevención de la violencia escolar y la construcción de una ciudadanía global. El estudio muestra que los principios de Educación para la paz y la formación de la ciudadanía globales inspirados en la Unesco son importantes alternativas para la promoción y la construcción de culturas de paz.

Palabras clave: Liderazgo Juvenil. Ciudadanía Global. Culturas de Paz. Prevención de la Violencia. 


\section{References}

ABRAMOVAY, M.; CASTRO, M. G.; SILVA, A. P. Diagnóstico participativo das violências nas escolas: falam os jovens. Rio de Janeiro: Flacso, 2016.

ALMEIDA, C. D.; OLIVEIRA, S. B.; BRUM, L. S. Da comunicação não-violenta à cultura de paz: círculos, narrativas e contribuições. Revista Observatório, Palmas, v. 5, n. 4, p. 463-480, jul./set. 2019. https://doi. org/10.20873/uft.2447-4266.2017v5n4p463

BOSCHI, H. "Cultura de paz": gênese de uma fórmula entre discursos de guerra e violência. Trabalhos em Linguística Aplicada, Campinas, v. 57, n.2, p. 848-876, maio/ago. 2018. https://doi.org/10.1590/010318138651922366471

BRASIL. Constituição da República Federativa do Brasil: promulgada em 5 de outubro de 1988. 4. ed. São Paulo: Saraiva, 1990.

BRASIL. Lei no 9.394, de 20 de dezembro de 1996. Estabelece as diretrizes e bases da educação nacional. Diário Oficial da União, Brasília, DF, 23 dez. 1996.

BRASIL. Lei no 13.005, de 25 de junho de 2014. Aprova o Plano Nacional de Educação - PNE e dá outras providências. Diário Oficial da União, Brasília, DF, 26 jun. 2014.

CALIMAN, G. Paradigmas da exclusão social. Brasília, DF: Universa Unesco, 2008.

CALIMAN, G.; VASCONCELOS, I. C. O (orgs.). Jovens universitários: entre a inclusão e a exclusão. Brasília, DF: Cátedra Unesco de Juventude, Educação e Sociedade, 2019.

CHRISPINO, A.; DUSI, M. L. H. M. Uma proposta de modelagem de política pública para a redução da violência escolar e promoção da Cultura da Paz. Ensaio: Avaliação e Políticas Públicas em Educação, Rio de Janeiro, v. 16, n. 61, p. 597-624, out./dez. 2008. https://doi.org/10.1590/S010440362008000400007

COHEN, A. K. Delinquent boys: the culture of the gang. New York: The Free, 1955.

CORDE. Declaração de Salamanca e linha de ação sobre necessidades educativas especiais. Brasília, DF: 2004. Disponível em: http://portal.mec.gov. br/seesp/arquivos/pdf/salamanca.pdf. Acesso em: 12 nov 2017. 
DELORS, J. et al. Educação: um tesouro a descobrir. São Paulo: Cortez; Unesco, 1998.

DISKIN, L.; NOLETO, M. J. (orgs.). Cultura de paz: da reflexão à ação. Brasília, DF: Unesco; São Paulo: Associação Palas Athena, 2010.

DUBET, F. Sociologie de l'expérience. Paris: Seuil, 1994.

FREIRE, P. Pedagogia da autonomia: saberes necessários à prática educativa. 9. ed. São Paulo: Paz e Terra, 1998.

FREIRE, P. Pedagogia da tolerância. São Paulo: Unesp, 2005.

GADOTTI, M. Escola Cidadã e educação para e pela cidadania. [S. 1.], 1997. Disponível em: http://www.acervo.paulofreire.org:8080/jspui/ bitstream/7891/1645/3/FPF_PTPF_13_009.pdf. Acesso em: 16 jan. 2020.

GOMES, C. A. et al. Educação para a cidadania. In: TODOS PELA EDUCAÇÂO (ed.). Justiça pela qualidade na educação. São Paulo: Saraiva, 2013. p. 687-707.

GOMES, C. A.; NASCIMENTO, G. A. F.; KOEHLER, S. M. F. (eds.). Culturas de violência, culturas de paz. Curitiba: CRV, 2012.

GUIMARÃES-IOSIF, R.; SHULTZ, L. Overcoming school violence: challenges and potential of Unesco Associated Schools in Brazil, Canada and Mozambique. Revista Interaç̧ões, Santarém, Portugal, v. 11, n. 38, número especial, p. 225-244, 2015. https://doi.org/10.25755/int.8499

HIRSCHI, T. Causes of delinquency. New Brunswick: Transaction, 2005.

MILLER, W. Lower class culture as generating milieu of gang delinquency. Journal of Social Issues, [s. 1.], v. 14, n. 3, p. 5-19, Summer 1958. https://doi.org/10.1111/j.1540-4560.1958.tb01413.x

NOLETO, M.J. Abrindo espaços: educação e cultura para a paz. 3. ed. Brasília, DF: Unesco, 2004.

PELIZZOLI, M. Cultura de paz restaurativa. In: PELIZZOLI, M. L. (org.). Justiça restaurativa: caminhos da pacificação social. Caxias do Sul: Ed. da UCS; Recife: Ed. da UFPE, 2015. p. 13-45.

SEVERINO, J. A. Universidade, ciência e formação acadêmica. In: SEVERINO, J. A. Metodologia do trabalho científico. São Paulo: Cortez, 2007. p. 21-36. 
SHAW, C. R.; MCKAY, H. D. Juvenile delinquency and urban areas. Chicago: The University of Chicago Press, 1942.

SILVA, E. R. A.; OLIVEIRA, R. M. (eds.). Os jovens adolescentes no Brasil: a situação socioeconômica, a violência e o sistema de justiça juvenil. In: SILVA, E. R. A.; BOTELHO, R. U. Dimensões da experiência juvenil brasileira e novos desafios às políticas públicas. Brasília, DF: Ipea, 2016. p. 293-329.

SIVERES, L. (org.). A extensão como um princípio de aprendizagem. Brasília, DF: LiberLivro, 2013.

SUTHERLAND, E. H. White-collar criminality. American Sociological Review, New York, v. 5, n. 1, p. 1-12, Feb. 1940.

UNESCO. Education 2030. Déclaration d'Incheon: vers une éducation inclusive et équitable de qualité et un apprentissage tout au long de la vie pour tous. Paris, 2015.

VASCONCELOS, I. C. O; LIRA, A.; SOARES, I. P. Jovens universitários em silêncio no mundo das informações: casos de liberação. Ensaio: Avaliação e Políticas Públicas em Educação, Rio de Janeiro, v. 27, n. 104, p.499-520, jul./set. 2019. https://doi.org/10.1590/s0104-40362019002701552

WAISELFISZ, J. J. Mapa da violência: homicídios por armas de fogo no Brasil 2016. Brasília, DF: Flacso, 2016. 


\section{Information about authors}

Geraldo Caliman: $\mathrm{PhD}$ in Education, Salesian Pontifical University in Rome, Professor at Master's and Doctorate Program in Education at the Catholic University of Brasília. Contact: ger.caliman@gmail.com

iD http://orcid.org/0000-0003-2051-9646

Ranilce Mascarenhas Guimaraes-Iosif: PhD in Social Policy, University of Brasília. Professor at Faculty of Education, University of Alberta, Canada. Contact: ranilceguimaraes@yahoo.com.br

iD http://orcid.org/0000-0002-5146-293X

José Ivaldo Araujo de Lucena: Master in Education at the Catholic University of Brasília. Professor at Catholic University of Brasília. Contact: joseivaldoucb@gmail.com iD http://orcid.org/0000-0002-3180-7128

Vanildes Gonçalves dos Santos: Master in Social Sciences from the Pontifical Catholic University of São Paulo. Professor at Catholic University of Brasília. Contact: vanildesucb@gmail.com

iD http://orcid.org/0000-0002-3496-6853 